\title{
Influence of strawberry jam color and phenolic compounds on acceptance during storage ${ }^{1}$
}

\author{
Lívia de Lacerda de Oliveira Pineli ${ }^{2}$, Celso Luiz Moretti ${ }^{3}$, Marileusa Chiarello ${ }^{4}$, Lauro Melo ${ }^{5}$
}

http://dx.doi.org/10.1590/0034-737X201562030002

\begin{abstract}
The objective of this study was to evaluate the influence of the color and phenolic compounds of strawberry jam on acceptance during storage. Jams were processed, stored for 120 days and evaluated monthly for chromatic characteristics, total phenolic compounds, total anthocyanins (ANT), total ellagic acid (TEA), flavonoids and free ellagic acid (FEA), and sensory acceptance as well. Data were submitted to analysis of variance (ANOVA) and the means were compared by the Least Significant Difference (LSD). Cluster Analysis and Partial Least Square Regression (PLS) were performed to investigate the relationships between instrumental data and acceptance. Contents of ANT, TEA and redness decreased during storage. Other chemical characteristics and sensory acceptance showed a nonlinear behavior. Higher acceptance was observed after 60 days, suggesting a trend of quality improvement followed by decline to the initial levels. The same trend was observed for lightness, non-pigment flavonoids and FEA. According to PLS map, for consumers in cluster 2, acceptance was associated to jams at 60 days and to luminosity, FEA, and non-pigment flavonoids. For cluster 1, a positive association between flavor liking, jam at initial storage, and the contents of TEA and ANT was indicated. Jams at 120 days were positively associated to hue and negatively associated to color liking, for cluster 1 . Color and texture were positively correlated to overall liking for cluster 2, whereas for cluster 1, overall acceptance seemed to be more associated to flavor liking. Changes in color and phenolic compounds slightly influenced the acceptance of strawberry jams, but in different ways for consumers clusters.
\end{abstract}

Key words: acceptance, antioxidants, fruit processing, storage, Partial Least Square Regression (PLS).

\section{RESUMO}

\section{Influência da cor e de compostos fenólicos de geleia de morango na aceitação durante $o$ armazenamento}

Este estudo teve como objetivo avaliar a influência da cor e de compostos fenólicos sobre a aceitação de geleia de morango durante o armazenamento. Geleias foram processadas, armazenadas por 120 dias e avaliadas mensalmente para as características cromáticas, compostos fenólicos totais, antocianinas totais (ANT), ácido elágico total (TEA), flavonoides e ácido elágico livre (FEA), além de aceitação sensorial. Os dados foram submetidos à análise de variância (ANOVA) e as médias foram comparadas pelo teste de diferença mínima significativa (LSD). Análises de Cluster e de Regressão por quadrados mínimos parciais (PLS) foram realizadas para investigar as relações entre os dados instrumentais e a aceitação. ANT, TEA e a tonalidade vermelha diminuíram durante o armazenamento. Outras características químicas e aceitação sensorial mostraram comportamento não linear. Mai-

\footnotetext{
Submitted on 10/25/2013 and approved on 04/14/2015.

${ }^{1}$ This work is part of PhD research of the first author. Financial support: CNPq.

2 Universidade de Brasília, Brasilia, DF, Brazil. liviapineli@unb.br

Embrapa Hortaliças, Brasília, DF, Brazil. celso.moretti@embrapa.br

${ }^{4}$ Universidade Catolica de Brasília, Brasilia, DF, Brazil. mdc@pos.ucb.br

${ }_{5}^{5}$ Universidade Federal do Rio de Janeiro, Rio de Janeiro, RJ, Brazil. lauro@eq.ufrj.br

*Corresponding author: liviapineli@unb.br
} 
or aceitação foi observada após 60 dias, o que sugere uma tendência de crescimento da qualidade seguida de declínio para os níveis iniciais. A mesma tendência foi observada para a luminosidade, flavonoides não-pigmentares e FEA. De acordo com o mapa PLS, para os consumidores do grupo 2, a aceitação foi associada às geleias com 60 dias e a luminosidade, FEA, e flavonoides não-pigmentares. Para cluster 1, foi indicada uma associação positiva entre a aceitação do sabor, geleias no início do armazenamento, e as quantidades de TEA e de ANT. Geleias com 120 dias foram associadas positivamente à tonalidade (hue) e negativamente associadas com a aceitação da cor, para grupo 1. Cor e textura foram positivamente correlacionadas com a aceitação global para o grupo 2, enquanto que para o grupo 1, aceitação global parece estar mais associada à aceitação do sabor. Concluiu-se que as mudanças na cor e nos compostos fenólicos influenciaram levemente a aceitação de geleias de morango, mas de maneiras diferentes para os grupos de consumidores.

Palavras-Chave: processamento de frutas, aceitação, antioxidantes, armazenamento, regressão quadrados mínimos parciais (PLS).

\section{INTRODUCTION}

Strawberries (Fragaria x ananassa Duch.) are used in many recipes and desserts. It has high contents of vitamin $\mathrm{C}$ and health-promoting phenolic compounds (Giampieri et al., 2012). Seasonality and high perishability are the major issues and the main reasons for the processing of such fruit (Pinto et al., 2007).

Fruit jams are manufactured by combining fruit and sugar in similar ratios, and then cooking the mixture, to obtain a tasty product with sufficient high sugar content with satisfactory maintenance qualities (Downing, 1996). According to Alves et al. (2008), jams are made to preserve the fruit so they can be consumed when they are out of season, and, when well processed, they retain, in great part, their nutritional and sensory characteristics for longer periods, making transportation, storage and commercialization easier.

Antioxidants from fruits and vegetables are considered an important protection factor against oxidative stress and its deleterious consequences to human health. Strawberry, a very popular berry with high visual appeal and desirable flavor, is also considered a good source of antioxidants, mainly because of its high contents of vitamin $\mathrm{C}$ and phenolic compounds. Hydroxybenzoic acids (gallic and ellagic acids), hydroxycinnamic acids (p-cumaric), hydrolysable tannins (ellagitannins), flavonols (quercetin, kaempferol and myricetin), flavan-3-ols (catequins), and anthocyanins are the phenolic classes commonly found in strawberries. In addition, pelargonidin-3-glycoside is the most important flavonoid pigment (Seeram et al., 2006). Phenolics are also associated with bitterness, by activating distinct human bitter taste receptors (Soares et al, 2013). Therefore, it is important to consider that the protective effect of antioxidants and their sensory properties can be type- and dose-dependent and that contents of phenolic compounds in strawberries may vary due to many factors, such as genotype and growing conditions, processing and storage (Pineli et al., 2011, 2012a e b; Tiwari et al., 2009a,b, Wicklund et al., 2005).

Even though the positive effects of fruit on human health are well-known, flavor and color are the most important factors for the selection of processed fruit derivatives by consumers. Strawberry products with an attractive and stable color tend to be associated with high quality. Anthocyanins are the most important pigments in strawberries, pelargonidin (bright red color) is the predominant pigment and cyanidin (dark red color) is the least important one (Gossinger et al., 2009). Anthocyanin pigments are unstable and susceptible to degradation during heat processing and storage (Kirka et al., 2007).

Jams have a one-year shelf-life, according to the product labels. However, as part of the design of this study, six supermarkets were visited and the managers reported that the retail market usually estimates a period between three and four months as the real shelf-life for this product. It has been reported that the necessity of stock turnover and color changes for some fruit jams are the main limiting factors for the time the market keeps the jams in retail. Then, the evaluation of quality and antioxidant characteristics of jams over this shorter period of time are important, considering that, generally, consumers buy the product up to four months after the processing.

The objective of this work was to evaluate the effects of color and concentrations of phenolics on the acceptance of strawberry jams during storage time to identify physical and chemical variables that could be related to the acceptance of these jams over 120 days of storage. 


\section{MATERIALAND METHODS}

\section{Raw material and jam processing}

'Camino Real' strawberries, grown in the Federal District $\left(15^{\circ} 41^{\prime} \mathrm{S}, 48^{\circ} 10^{\prime} \mathrm{W}, 1200 \mathrm{~m}\right.$ above the sea level), were harvested at full ripe stage from a commercial field. Fruits $(40 \mathrm{~kg})$ were sorted, washed and sanitized. After removal of the leaves, the strawberries were manually diced. Jam formulation was $57 \%$ of fruit, $43 \%(\mathrm{w} / \mathrm{w})$ of sugar and $0.5 \%$ of pectin (CPKELCO). Fruits and sugar with pectin were placed in a 300-L steam kettle (Quartinox QX-3, Brazil). After one hour at $25 \pm 1{ }^{\circ} \mathrm{C}$ under slow stirring, the steam was then fed to the equipment so the heating and concentration processes could start. The mixture was boiled to a final concentration of $66^{\circ} \mathrm{Brix}$, measured with a refractometer (Instrutherm, RT-280, Brazil). The final $\mathrm{pH}$ was 3.2. Jam was hot-packed at $85-90{ }^{\circ} \mathrm{C}$ in $250 \mathrm{~mL}$ glass jars, immediately sealed with plastisol lined metal lids, and inverted for five minutes for lids sterilization. Jars were returned to normal position for air-cooling. Jams were stored for 120 days at $20{ }^{\circ} \mathrm{C}$. At the initial time, and every 30 days, three experimental units were immediately frozen at $-80{ }^{\circ} \mathrm{C}$ using liquid nitrogen and an ultrafreezer. At the end of 120 days, all samples were simultaneously analyzed for color, phenolics and sensory acceptance.

\section{Chromatic characteristics}

The color of the jams was quantified with a Minolta (CR-400b) Chromameter (Japan). Measurements were expressed as $\mathrm{L}^{*}$ value (dark to light), chroma ( $C^{*}$, intensity of color) and hue angle $\left(h^{\circ}\right.$, actual color, or redness), calculated using the equations:

$C^{*}=\left(\mathrm{a}^{2}+\mathrm{b}^{2}\right)^{1 / 2}($ Eq. 1$) ; h^{\circ}=\tan ^{-1}$ (b/a) (Eq. 2). Hue classification was made according to the scale presented by Mcguire $(1992$, where $0=$ purple red; $90=$ yellow; $180=$ blue-to-green and $270=$ blue.

Two readings of each experimental unit were taken using a cuvette and the average values for each treatment were calculated.

\section{Extraction and measurement of phenolic compounds and antioxidant activity assays}

\section{Sample extraction}

Jams were weighed $(10 \mathrm{~g})$ and homogenized with $100 \mathrm{~mL}$ of $80 \%$ acetone, as described by Shin et al. (2007 The homogenate was filtered and acetone was rotaevaporated at $45^{\circ} \mathrm{C}$ for $30 \mathrm{~min}$. Deionized water was added to each sample in order to bring them to the final volume of $10 \mathrm{~mL}$. The extracts were kept frozen at " $80{ }^{\circ} \mathrm{C}$ until analysis and were used for the measurement of phenolic compounds and antioxidant activity assays. All extractions were done in duplicate, and the subsequent assays were run in triplicate.

\section{Determination of total phenolic compounds (TPC)}

Total phenolic compounds (TPC) were quantified using a modified Folin-Ciocalteau colorimetric method (Pineli et al., 2011; Singleton et al., 1999). Results were expressed as mg gallic acid equivalent.kg"' $\mathrm{FW}$.

\section{Determination of total anthocyanins (ANT)}

Anthocyanins were determined according to Shin et al. (2007) with some modifications (Pineli et al., 2011). Total anthocyanins content was calculated using the extinction coefficient (å) equal to $3.6 \times 10^{6} \mathrm{~mol}^{\prime \prime 1} \mathrm{~m}^{\prime \prime}$. Results were expressed as mg pelargonidin-3-glucoside equivalent.kg"'FW.

\section{Determination of total ellagic acid (TEA)}

Extraction and hydrolysis of ellagitannins methods, and analysis of TEA by HPLC-UV-Vis were modified by Pineli et al. (2011), from Pinto et al. (2007). Results were expressed as mg ellagic acid. $\mathrm{kg}^{-1} \mathrm{FW}$.

\section{Determination of flavonoids and free ellagic acid (FEA)}

Extraction was performed according to Pinto et al. (2007) with some modifications (Pineli et al., 2011). Identification and quantification of flavonoids and free ellagic acid were achieved using HPLC-DAD. Neutral flavonoids (anthocyanins) were analyzed at $520 \mathrm{~nm}$, and acid flavonoids (quercetin, quercetin-3-rutinoside, kaempferol, catechin and epicatechin) and ellagic acid, at $260 \mathrm{~nm}$.

\section{Acceptance testing}

Consumer acceptance test was carried out to evaluate flavor, color, texture and overall liking of the strawberry jams. Tests were performed in the Sensory Evaluation Laboratory of the Catholic University of Brasilia. A 9point hedonic scale, from "dislike extremely" to "like extremely", was used with a group of 96 untrained consumers. Those consumers were students, professors and employees of the university, $65 \%$ female and $46 \%$ between 18 and 30 years, $38 \%$ between 31 and 50 years and $18 \%$ older than 50 years old, and they evaluated all samples (Stone \& Sidel, 2004). Consumers received a $10 \mathrm{~g}$ sample on a biscuit used as food vehicle. Samples were coded with three-digit random numbers. Tests were carried out in individual air-conditioned booths. The samples, previously thawed, were served monadically in randomized order. 


\section{Statistical Analysis}

Experiments were carried out in a completely randomized design, with one treatment and 5 storage periods $(0,30,60,90$ and 120 days) and three replicates. Treatments were labeled as J0, J30, J60, J90 and J120, according to the storage time. The experimental unit was a jar with $250 \pm 10 \mathrm{~g}$ of jam. All instrumental analyses were carried out in triplicate. Data were submitted to analysis of variance (ANOVA) and the means were compared by Least Significant Difference (LSD) test (p d" 0.05). Cluster Analysis was performed on overall liking sensory data in XLSTAT software version 2010 (Addinsoft, France), using Pearson correlation matrix data. Instrumental data were related to the consumer acceptance using Partial Least Square Regression (PLS) with XLSTAT.

\section{RESULTS AND DISCUSSION}

\section{Effects on color}

Chromatic characteristics showed different trends of changes over storage at $20{ }^{\circ} \mathrm{C}$ (Table 1). Lightness increased by $8 \%$ until day 60 and, after that, decreased to values similar to those found at the beginning ( 0 day) of the experiment. Redness decreased gradually over storage. The loss of redness was more significant between 90 and 120 days (19.6\%). Color saturation $\left(\mathrm{C}^{*}\right)$ showed an oscillatory behavior, with the highest values at 30 and 90 days. The trend of loss of redness was also found by Ngo et al. (2007), who found a major increase in the $\mathrm{h}^{\mathrm{o}}$ value (lower redness) of 'Toten' strawberry jams within the first 3 weeks of storage at $38^{\circ} \mathrm{C}$ whereas it took 9 weeks for changes in $\mathrm{h}^{\circ}$ at $21^{\circ} \mathrm{C}$. At the same temperature, $\mathrm{L}^{*}$ was higher after 3 weeks but a slight decrease in this variable was noticed until the end of storage time, which is in accordance with our results.

\section{Effects on phenolics}

Total phenolic compounds (TPC) were about $12 \%$ lower after 30 days of storage but the contents increased again until 120 days and they were similar to those found at the initial time. This result may suggest that some structural changes in phenolics may have happened after 30 days. Koplotek et al. (2005) argued that processing or storage conditions lead to copigmentation and selfassociation of molecules, reducing the number of hydroxyl groups available to react in Folin-Ciocalteau colorimetric assay, apparently reducing the concentration of TPC. On the other hand, the release of monomers from polymeric polyphenols also lead to higher values of TPC by FolinCiocalteau assay, which could explain the apparent increase of phenolics during storage.

Total anthocyanins (ANT) content decreased gradually until 120 days of storage. The final content was about 50\% lower in relation to initial jams ( $\mathrm{p}<$ 0.0001). Higher losses of individual anthocyanins were found between 30 and 60 days, when P-3 g and Cy decreased $75 \%(\mathrm{p}<0.0001)$ and $84 \%(\mathrm{p}<0.0001)$, respectively (Table 1 ). The $\mathrm{Cy}$ was not detected at 120 days of storage. According to Rein (2005) anthocyanins are highly unstable molecules in food matrix. The color stability of these pigments is strongly affected by $\mathrm{pH}$, solvents, temperature, anthocyanin concentration and structure, oxygen, light, enzymes, and other accompanying substances. The high difference found between total and individual losses of anthocyanins may be explained by differences between analytical methods (spectrophotometry versus HPLC) or even by the batocromic shift of about 5 to $20 \mathrm{~nm}$ usually found during intramolecular anthocyanins copigmentation (Boulton, 2001), which resulted in the exclusive quantification of free P-3 $\mathrm{g}$ and $\mathrm{Cy}$ in the wavelength applied in this study.

Table 1. Chromatic characteristics and phenolic compounds of strawberries jams stored for 120 days

\begin{tabular}{|c|c|c|c|c|c|}
\hline Days of storage & J0 & $\mathbf{J 3 0}$ & $\mathbf{J 6 0}$ & J90 & J120 \\
\hline$\overline{\text { Luminosity }\left(\mathrm{L}^{*}\right)}$ & $21.22(0.26)^{b}$ & $20.18(0.5)^{b}$ & $22.89(0.61)^{\mathrm{a}}$ & $21.17(0.86)^{\mathrm{b}}$ & $20.93(1.59)^{b}$ \\
\hline Hue & $21.76(0.57)^{\mathrm{c}}$ & $24.00(0.53)^{b}$ & $24.03(1.49)^{\mathrm{b}}$ & $24.88(0.78)^{\mathrm{b}}$ & $29.78(1.03)^{\mathrm{a}}$ \\
\hline Chroma $\left(C^{*}\right)$ & $8.01(0.71)^{\mathrm{bc}}$ & $10.11(1.89)^{\mathrm{a}}$ & $6.88(0.21)^{\mathrm{c}}$ & $9.10(1.02)^{\mathrm{ab}}$ & $7.21(0.83)^{\mathrm{bc}}$ \\
\hline Total Phenolic Compounds(mg/100 g FW) & $235.84(10.15)^{\mathrm{a}}$ & $210.50(4.91)^{b}$ & $226.57(12.42)^{\mathrm{ab}}$ & $237.99(9.95)^{\mathrm{a}}$ & $236.48(7.02)^{\mathrm{a}}$ \\
\hline Total Anthocyanins(mg/100 g FW) & $25.80(0.63)^{\mathrm{a}}$ & $21.13(0.09)^{\mathrm{b}}$ & $17.52(0.25)^{\mathrm{c}}$ & $14.75(1.59)^{\mathrm{d}}$ & $13.54(0.70)^{\mathrm{d}}$ \\
\hline Pelargonidin-3-glucoside(mg/100 g FW) & $25.88(1.76)^{\mathrm{a}}$ & $13.69(1.52)^{\mathrm{b}}$ & $3.08(0.09)^{\mathrm{c}}$ & $4.18(0.25)^{\mathrm{c}}$ & $2.49(0.21)^{\mathrm{c}}$ \\
\hline Cyanidins"(mg/100 g FW) & $0.95(0.15)^{\mathrm{a}}$ & $0.63(0.08)^{\mathrm{b}}$ & $0.10(0.02)^{\mathrm{c}}$ & $0.11(0.02)^{c}$ & n.d. \\
\hline Total ellagic acid(mg/100 g FW) & $27.51(0.73)^{\mathrm{a}}$ & $23.04(2.15)^{\mathrm{b}}$ & $22.33(0.91)^{b}$ & $23.07(1.31)^{\mathrm{b}}$ & $22.30(2.07)^{\mathrm{b}}$ \\
\hline Free ellagic acid(mg/100 g FW) & $1.23(0.15)^{\mathrm{bc}}$ & $1.57(0.02)^{\mathrm{b}}$ & $2.01(0.36)^{\mathrm{a}}$ & $1.40(0.06)^{b}$ & $0.91(0.14)^{\mathrm{c}}$ \\
\hline Catechin $(\mathrm{mg} / 100 \mathrm{~g} \mathrm{FW})$ & $4.72(0.42)^{\mathrm{c}}$ & $10.72(1.71)^{\mathrm{b}}$ & $13.25(1.03)^{\mathrm{a}}$ & $9.87(1.62)^{\mathrm{b}}$ & $9.28(0.56)^{b}$ \\
\hline Epicatechin(mg/100 g FW) & $1.68(0.18)^{\mathrm{c}}$ & $2.60(0.13)^{\mathrm{ab}}$ & $2.98(0.44)^{\mathrm{a}}$ & $2.27(0.23)^{b}$ & $2.27(0.23)^{b}$ \\
\hline Quercetins $^{* *}(\mathrm{mg} / 100 \mathrm{~g} \mathrm{FW})$ & $0.19(0.01)^{\mathrm{d}}$ & $1.95(0.23)^{\mathrm{a}}$ & $1.35(0.13)^{\mathrm{b}}$ & $1.31(0.12)^{\mathrm{b}}$ & $1.01(0.03)^{\mathrm{c}}$ \\
\hline
\end{tabular}

${ }^{*}$ Cyanidins are the sum of the aglycone and cyanidin-3-glucoside. ** Quercetins are the sum of the aglycone and quercetin3-rutinoside (rutin); jam treatments at 0 (J0), 30 (J30), 60 (J60), 90 (J90) and 120 (J120) days of storage; values are expressed as means \pm SD (SD for $n=9$ of three extraction replicates). Means in the same row with common letters are not significantly different $(p<0.05)$. n.d. - not detected 
Total ellagic acid (TEA) was about $20 \%$ lower ( $\mathrm{p}<$ $0.05)$ after 30 days of storage, with no further significant changes $(\mathrm{p}>0.05)$. Free ellagic acid (FEA) increased about $63 \%$. However, it decreased again by 2.2-fold until 120 days (Table 1). Similar trends were observed for the other studied flavonoids. Quercetins (determined as quercetin aglycone and rutin) increased by 10 -fold until 30 days followed by a decline of $48 \%$. Catechin and epicatechin were significantly higher at 60 days, and the amount of catechin and epicatechin were 2.8 and 1.8fold higher respectively, compared to the initial jams. Further significant decrease of catechin (42.8\%) and epicatechin (31.2\%) occurred until 120 days (Table 1). Kaempferol was detected in trace levels or not detected, and it was not regarded in statistical analysis.

The concentrations of TEA in strawberry jams are comparable to those found by Pineli et al. (2012a) in strawberries. The role of ellagic acid, the main flavonoid found in strawberries and corresponding to more than $50 \%$ of their phenolic compounds (Häkkinen et al., 2000) have been extensively studied. Recent works report as some of biological activities of ellagic acid the following: protection against hepatic injuries $(\mathrm{Gu}$ et $a l ., 2014$ ), an antiepileptic activity (Dhingra \& Jangra, 2014), amelioration of renal functions (Ahad et al., 2014), anti-inflammatory effects via antioxidant mechanisms (El-Shitany et al., 2014, Marin et al., 2013), inhibition of adipocytes differentiation (Kang et al., 2014), antimycobacterial acitivity (Fyhrquist et al., 2014), besides the ability to attenuate growth and survival of cancer cells (Alfredsson et al., 2014), among other properties.

According to Brownmiller et al. (2009), catechin and epicatechin are found as such or in polymeric form, called procyanidins, which are mixtures of oligomers and polymers consisting of catechin and/or epicatechin units linked mainly through C4 B8 bonds (B type). García-Falcon et al. (2007) studied the behavior of catechin and epicatechin monomers during the aging of wine and stated that oscillations in the levels of flavan3-ol monomers and polymers were probably the result of complex mutual polymerization-depolymerization processes accompanied by combination with some anthocyanins to give more stable pigments. The authors also reported an increase in catechin peaks after three and 12 months of wine storage, but the interference of cis-caffeic acid was considered in this case, as it increased during the wine aging and disturbed the quantification of the flavan-3-ols. According to the authors, hydrolysis of conjugated flavonols also result in the increase of myricetin, kaempherol and quercetin, which could explain the higher levels of quantified quercetins after 30 days in the present work.
Regarding sensory traits, it was also demonstrated that larger molecules tend to be less bitter and more astringent (Lesschaeve \& Noble, 2005). In the literature, it is stated that sweetness and bitterness are mutually suppressed in mixtures (Birch and Ogunmoyela, 1980; Caviño et al., 1990). Jams are sugar-rich products, so it is expected that phenolics bitterness is suppressed by sweetness effects. However, studies that evaluated the effect of phenolics on the flavor of a sugary product were not found by the authors of this paper.

The values of cathechins (47.2-132.5mg.kg- $\left.{ }^{-1} \mathrm{FW}\right)$ and epicatechins (16.8-29.8mg. $\left.\mathrm{kg}^{-1} \mathrm{FW}\right)$ of strawberry jams are comparable to those of black, green and white teas studied by Lin et al. (2003) and they may be relevant from the antioxidant and sensory standpoints. Further studies must be carried out to evaluate in what extent the changes found in the phenolics profile are sensorially detected and the wary it is related to the quality.

\section{Effects on acceptance}

Table 2 shows the results of ANOVA and LSD comparison for the sensory acceptance, attributes of color, flavor, texture and overall liking of the strawberry jams.

Acceptance did not decrease linearly during storage time. A higher acceptance of color was found in jams at 60 and 90 days. Significant differences in flavor liking were found between jams at 60 and 120 days, and the latter treatment was less accepted. Jams with 60 days of storage also presented the highest texture acceptance of all storage time, except for 90 days. In addition, the highest overall liking scores were attributed to samples at 60 and 90 days (not statistically differing from 30 days), followed by products stored for 0 and 120 days.

Cluster analysis resulted in clusters 1 and 2, with 55 and 41 consumers, respectively. The means for overall liking, color and flavor of cluster 1 were approximately 8.0 for all storage times, with no statistical differences (Table 3). For texture results from cluster 1, a difference was found between jams stored for 90 days (higher scores) and that for 120 days ( $<<0.05)$.

Flavor and texture acceptance of jams with 60 days of storage did not differ ( $p>0.05$ ) between clusters 1 and 2. For the other attributes and storage times, acceptance for cluster 1 was the largest $(\mathrm{p}<0.05)$.

For cluster 2, no differences were found for jams stored for 0 and 120 days $(\mathrm{p}<0.05$ ) but their means were significantly lower than for jams stored for 60 days, indicating a trend of improvement in the quality until the middle of storage, followed by a decline for this cluster. Since similar behavior was observed for some chemical variables, it was chosen to investigate the correlation between the instrumental variables with the acceptance. 
The improvement in quality over time is frequently reported for wines, where time-dependent changes in phenolic profiles are also observed (Weber et al., 2013).

\section{Acceptance and instrumental data relationships}

The relationships among overall liking, the acceptance of color, flavor and texture and instrumental variables were taken by PLS regression (Figure 1). PLS is a modeling approach that is applied when predictive variables are inter-correlated (Tang et al., 2000).

PLS confirmed that jams at 60 days were more associated to overall liking, texture, color and flavor acceptances for cluster 2, indicating that jam sensory quality is enhanced over a period of time, followed by a decline. Higher acceptance of these jams by cluster 2 seems to be associated to luminosity, free ellagic acid, quercetins, catequin and epicatequin, which indicate that the depolimerization of condensed and hydrolysable tannins and the associated changes in phenolics, can be positive for the quality of strawberry jams, for some consumers. Acceptance of cluster 2 was negatively associated to TPC, which suggests that copigmentation and self-association of molecules, reported to reduce apparently TPC in jams (Koplotek et al., 2005), can also be positive for sensory quality of strawberry jams.

For cluster 1, a positive association among flavor liking, jam at initial storage, and the contents of total ellagic acid and anthocyanins was indicated by PLS map. In addition, overall liking for cluster 1 was negatively associated to the contents of quercetin, catechin and epicatechin, in contrast to cluster 2. Even in a small extent, given that sugar can minimize these effects, it seemed that astringency and bitterness, related to the degree of polymerization of polyphenols, are the likely sources of this contrast of preferences. Hue (lack of redness) was positively correlated to jam at 120 days, which was negatively associated to color liking for cluster 1 . The vector of overall liking of cluster 1 showed up closer to the vector of flavor liking, while the vector of overall liking of cluster 2 was closer to the vectors of texture and color likings, suggesting a difference in the weights of the attributes in the overall acceptance for each group of consumers. Regarding the instrumental parameters of color and pigments, color acceptance for cluster 2 is more related to lightness, whereas for cluster, it 1 is more related to the amount of pigments.

For a better understanding of these changes, Quantitative Descriptive Analysis (QDA) should be carried out to elucidate the relationships found among the studied variables and to understand how these changes, probably related to polimerization, depolimerization and copigmentation, can affect flavor descriptive attributes of the strawberry jams. In addition, sensory descriptive attributes could be used as supplementary variables in the preference mapping in order to provide more highlights on the relationship between instrumental and acceptance data.

Miguel et al. (2009) used QDA to evaluate red color, flavor, and gel consistency of 'Osogrande' strawberry jams at 20,30 and $40{ }^{\circ} \mathrm{C}$ for $0,30,60,90$ and 180 days. The authors also found that intensities of these attributes were not linear, which is in accordance with the present study.

Table 2. Acceptance by attributes of strawberry jams stored for 120 days

\begin{tabular}{lccccc}
\hline Days of storage & $\mathbf{J 0}$ & $\mathbf{J 3 0}$ & $\mathbf{J 6 0}$ & $\mathbf{J 9 0}$ & J120 \\
\hline Color & $6.7(1.7)^{\mathrm{b}}$ & $7.1(1.5)^{\mathrm{b}}$ & $7.5(1.5)^{\mathrm{a}}$ & $7.4(1.5)^{\mathrm{ab}}$ & $6.7(1.8)^{\mathrm{b}}$ \\
Flavor & $7.5(1.7)^{\mathrm{ab}}$ & $7.7(1.5)^{\mathrm{ab}}$ & $7.9(1.3)^{\mathrm{a}}$ & $7.8(1.4)^{\mathrm{ab}}$ & $7.3(2.0)^{\mathrm{b}}$ \\
Texture & $6.7(1.9)^{\mathrm{b}}$ & $7.1(1.7)^{\mathrm{b}}$ & $7.5(1.6)^{\mathrm{a}}$ & $7.4(1.7)^{\mathrm{ab}}$ & $6.7(1.8)^{\mathrm{b}}$ \\
Overall liking & $7.1(1.7)^{\mathrm{b}}$ & $7.3(1.6)^{\mathrm{ab}}$ & $7.6(1.5)^{\mathrm{a}}$ & $7.7(1.2)^{\mathrm{a}}$ & $7.1(1.7)^{\mathrm{b}}$ \\
\hline
\end{tabular}

Same letters in a row indicate that the samples did not present statistical difference at a 5\% significance level considering Fisher's LSD test.

Values in parenthesis are the standard deviation.

Table 3. Clusters' acceptance by attributes of strawberry jams stored for 120 days

\begin{tabular}{lcccccc}
\hline Attribute & Days of storage & $\mathbf{J 0}$ & $\mathbf{J 3 0}$ & $\mathbf{J 6 0}$ & J90 & J120 \\
\hline \multirow{2}{*}{ Overall liking } & Cluster 1 $(\mathrm{n}=55)$ & $8.2(0.7)^{\mathrm{Aa}}$ & $8.1(0.8)^{\mathrm{Aa}}$ & $8.0(1.0)^{\mathrm{Aa}}$ & $8.2(0.7)^{\mathrm{Aa}}$ & $8.1(0.8)^{\mathrm{Aa}}$ \\
& Cluster 2 $(\mathrm{n}=41)$ & $5.7(1.6)^{\mathrm{Bb}}$ & $6.4(1.9)^{\mathrm{Bab}}$ & $7.0(1.9)^{\mathrm{Ba}}$ & $7.1(1.4)^{\mathrm{Ba}}$ & $5.9(1.7)^{\mathrm{Bb}}$ \\
\multirow{2}{*}{ Color } & Cluster 1 (n=55) & $8.2(0.9)^{\mathrm{Aa}}$ & $8.1(1.0)^{\mathrm{Aa}}$ & $8.2(1.1)^{\mathrm{Aa}}$ & $8.3(0.9)^{\mathrm{Aa}}$ & $8.0(1.2)^{\mathrm{Aa}}$ \\
& Cluster 2 $(\mathrm{n}=41)$ & $6.4(2.0)^{\mathrm{Bb}}$ & $7.1(1.8)^{\mathrm{Bab}}$ & $7.5(1.9)^{\mathrm{Ba}}$ & $7.0(1.8)^{\mathrm{Bab}}$ & $6.4(2.2)^{\mathrm{Bb}}$ \\
\multirow{2}{*}{ Flavor } & Cluster 1 (n=55) & $8.2(0.8)^{\mathrm{Aa}}$ & $7.9(1.0)^{\mathrm{Aa}}$ & $8.0(1.1)^{\mathrm{Aa}}$ & $8.3(0.9)^{\mathrm{Aa}}$ & $7.9(1.1)^{\mathrm{Aa}}$ \\
& Cluster 2 (n=41) & $6.5(2.0)^{\mathrm{Bbc}}$ & $6.9(1.8)^{\mathrm{Bab}}$ & $7.4(1.6)^{\mathrm{Aa}}$ & $7.0(1.7)^{\mathrm{Bab}}$ & $6.0(2.3)^{\mathrm{Bc}}$ \\
\multirow{2}{*}{ Texture } & Cluster 1 (n=55) & $7.8(1.0)^{\mathrm{Aab}}$ & $7.8(1.1)^{\mathrm{Aab}}$ & $7.8(1.3)^{\mathrm{Aab}}$ & $8.2(0.9)^{\mathrm{Aa}}$ & $7.7(1.1)^{\mathrm{Ab}}$ \\
& Cluster 2 $(\mathrm{n}=41)$ & $5.5(1.9)^{\mathrm{Bc}}$ & $6.2(2.0)^{\mathrm{Bbc}}$ & $7.2(1.8)^{\mathrm{Aa}}$ & $6.6(2.1)^{\mathrm{Bab}}$ & $5.6(1.8)^{\mathrm{Bc}}$ \\
\hline
\end{tabular}

Within each attribute, different uppercase letters in the same column mean a significant difference ( $p<0.05$ ) according to Two Sample $t$ test. Different lower case letters in the same row mean a significant difference $(\mathrm{p}<0.05)$ according to ANOVA and Fisher test $(\mathrm{p}<0.05)$. 


\section{Correlations with $\mathrm{t}$ on axes $\mathrm{t} 1$ and $\mathrm{t} 2$}

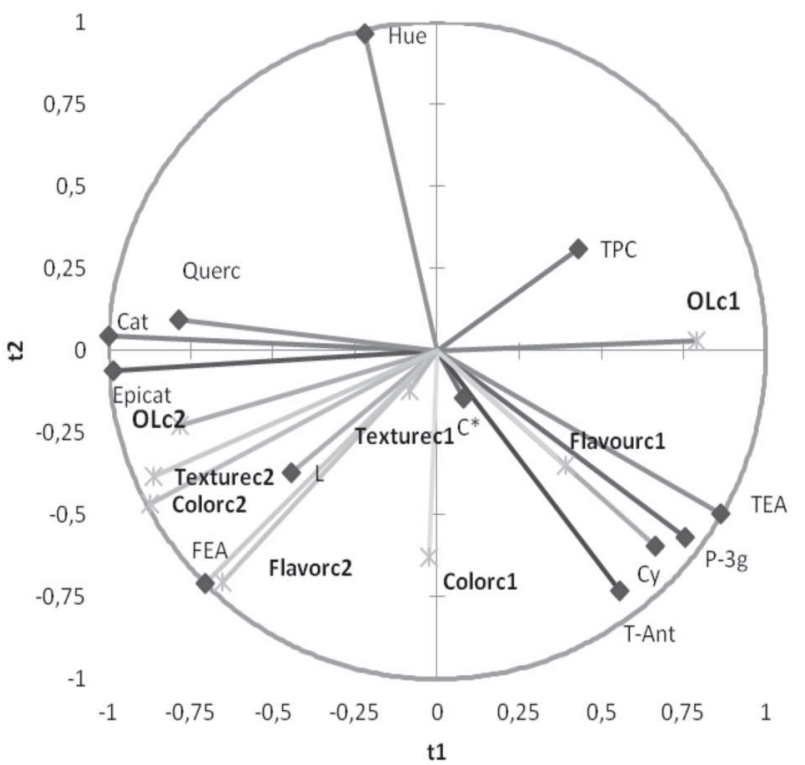

A

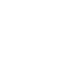

Figure 1. Relationship between Overall Liking of each cluster (OLc1 and OLc2) with attribute likings (color, flavor, texture of clusters $1-\mathrm{c} 1$ and 2-c2 ) and instrumental data (a) and the positions of the samples (b). Treatments are as follows: jams stored for 120 days (J0 to J120). Variables: L- Luminosity; Hue; $\mathrm{C}^{*}$ - Chroma; TPC-total phenolic compounds; T-Ant-total anthocyanins; TEA-total ellagic acid; FEA - free ellagic acid; P-3g - pelargonidin-3-glucoside; Cy - cyanindins; Cat- catechin, Epicat- epicatechin, Querc-quercetins.

At $20{ }^{\circ} \mathrm{C}$, they reported that red color was significantly lower only at 90 days, flavor was higher at 60 and 90 days and declined again until 180 days and gel consistency increased between 30 and 90 days and decreased at 180 days to the same level of the initial jam. Although the changes were very small, the impact of attributes changes on acceptance, as observed in this work, can orientate the shelf-life practiced by retail market.

Probably, sugar in jams minimizes the effects of the changes in phenolics on bitterness and on texture over storage time. However, changes in color are of great interest for consumers and they can have an impact on the preferences when choosing in retail since brands are not necessarily presented at the same time of storage in the shelves.

\section{CONCLUSIONS}

Strawberry jams stored for 120 days present changes in phenolic compounds, affecting chromatic characteristics. Some changes are probably related to structural rearrangements than to degradation. The contents of phenolics in strawberry jams are comparable to that of important sources, such as raw strawberries and Camelia sinensis teas reported in literature. Sensory acceptance, evaluated in the presented study, varied slightly over storage time and were associated to chemical and color changes. Further studies should be carried out to investigate the way they influence antioxidant activity and descriptive sensory variables.

\section{ACKNOWLEDGMENTS}

We would like to thank the strawberry grower José Ricardo Aléscio, for supplying the strawberries used in the study. To PPPG/UCB, National Council of Science and Technology (CNPq), Embrapa Vegetables and Ministry of Science and Technology, for the financial support. To the consumers, that accepted to evaluate all the samples of jams.

\section{REFERENCES}

Ahad A, Ganai AA, Mujeeb M \& Siddiqui WA (2014) Ellagic acid, an NF-êB inhibitor, ameliorates renal function in experimental diabetic nephropathy. Chemico-Biological Interactions, 219:64-75.

Alfredsson CF, Ding M, Liang QL, Sundström BE \& Nanberg E (2014) Ellagic acid induces a dose- and time-dependent depolarization of mitochondria and activation of caspase- 9 and -3 in human neuroblastoma cells. Biomed. Pharmacotherap. 68:129-135.

Alves LR, Battochio JR, Cardoso JMP, Melo LLMM, Silva VS, Siqueira ACP \& Bolini HMA (2008) Time-intensity profile and internal preference mapping of strawberry jam. Journal of Sensory Studies, 23:125-135.

Birch GG \& Ogunmoyela G (1980) Taste properties of cocoa drinks with no added bitter/sweet sugar: intensity/time effects. Journal Food Technology, 15:549-55.

Boulton R (2001) The copigmentation of anthocyanins and its role in the color of red wine: A Critical Review. American Journal of Enology and Viticulture, 52:67-80.

Brownmmiller C, Howard LR \& Prior LR (2009) Processing and Storage Effects on Procyanidin Composition and Concentration of Processed Blueberry Products. Journal of Agricultural and Food Chemistry, 57:1896-1902. 
Calviño AM, García-Medina MR \& Cometto-Muñoz JE (1990) Interactions in caffeine-sucrose and coffee-sucrose mixtures: evidence of taste and flavor suppression. Chem Senses, 15:505-519.

Dhingra D \& Jangra A (2014) Antiepileptic activity of ellagic acid, a naturally occurring polyphenolic compound, in mice. Journal of Functional Foods, 10:364-369.

Downing DL (1996) Preserves (jams), jellies and related products. In: Downing DL (Ed.) A complete course in canning and related processes. $13^{\text {th }}$ ed. Baltimore, CTI Publications. p. 385-426.

El-Shitany NA, El-Bastawissy EA \& El-Desoky K (2014) Ellagic acid protects against carrageenan-induced acute inflammation through inhibition of nuclear factor kappa $\mathrm{B}$, inducible cyclooxygenase and proinflammatory cytokines and enhancement of interleukin-10 via an antioxidant mechanism. International Immunopharmacology, 19:290-299.

Fyhrquist P, Laakso I, Garcia Marco S, Julkunen-Tiitto R \& Hiltunen R (2014) Antimycobacterial activity of ellagitannin and ellagic acid derivate rich crude extracts and fractions of five selected species of Terminalia used for treatment of infectious diseases in African traditional medicine. South African Journal of Botany, 90:01-16.

García-Falcón MS, Pérez-Lamela C, Martínez-Carballo E \& Simal-Gándara J (2007) Determination of phenolic compounds in wines: Influence of bottle storage of young red wines on their evolution. Food Chemistry, 105:248-259.

Giampieri F, Tulipani S, Alvarez-Suarez JM, Quiles JL, Mezzetti B \& Battino M (2012) The strawberry: Composition, nutritional quality, and impact on human health. Nutrition, 28:09-19.

Gössinger M, Moritz S, Hermes M, Wendelin S, Scherbichler H, Halbwirth H, Stich K \& Berghofer E (2009) Effects of processing parameters on color stability of strawberry nectar from puree. Journal of Food Engineering, 90:171-178.

Gu L, Deng W, Liu Y, Jiang C, Sun L, Sun X, Xu Q \& Zhou H (2014) Ellagic acid protects Lipopolysaccharide/d-galactosamine-induced acute hepatic injury in mice. Internation Immunopharmacology, 22:341-345

Häkkinen SH, Kärenlampi SO, Mykkänen HM, Heinonen MI \& Törrönen AR (2000) Ellagic acid content in berries: Influence of domestic processing and storage. Europen Food Research and Technology, 212:75-80.

Kang I, Okla M \& Chung S (2014) Ellagic acid inhibits adipocyte differentiation through coactivator-associated arginine methyltransferase 1-mediated chromatin modification. Journal of Nutritional Biochemistry, 25:946-953.

Kirka A, Özcan M \& Lu C (2007) Storage stabillity of strawberry of jam color enhanced with black carrot juice concentrate. Journal of Food Processing Preservation, 31:531-545.

Klopotek Y, Otto K \& Böhm V (2005) Processing strawberries of different products alters content of vitamin $\mathrm{C}$, total phenolics, total anthocyanins, and antioxidant capacity. Journal of Agricultural and Food Chemistry, 53:5640-5646.

Lesschaeve I \& Noble AC (2005) Polyphenols: factors influencing their sensory properties and their effects on food and beverage preferences. American Journal of Clinical Nutrition, 81:330S-335S.

Lin YS, Tsai YJ, Tsay JS \& Lin JK (2003) Factors affecting the levels of tea polyphenols and caffeine in tea leaves. Journal of Agricultural and Food Chemistry, 51:1864-1873

Marín M, Giner RM, Ríos JL \& Recio MC (2013). Intestinal antiinflammatory activity of ellagic acid in the acute and chronic dextrane sulfate sodium models of mice colitis. Journal Ethnopharmacology, 150:925-934.
Mcguire RG (1992) Reporting of objective color measurements. HortScience, 27:1254-1255.

Miguel ACA, Albertini S \& Spoto MHF (2009) Kinetics of strawberry jelly degradation. Food Science Technology, 29:142-147.

Ngo T, Wrolstad RE \& Zhao Y (2007) Color quality of Oregon strawberries-Impact of genotype, composition, and processing. Journal of Food Science, 72:C25-C32.

Pineli LLO, Moretti CL, Santos MS, Campos AB, Brasileiro AV, Cordova AC \& Chiarello MD (2011) Antioxidants and other chemical and physical characteristics of two strawberry cultivars at different ripeness stages. Journal Food Composition and Analysis, 24:11-16.

Pineli LLO, Moretti CL, Rodrigues JSQ, Ferreira DB \& Chiarello MD (2012a) Variations in antioxidant properties of strawberries grown in Brazilian savannah and harvested in different seasons. Journal of the Science Food Agriculture, 92:831-838.

Pineli LLO, Moretti CL \& Chiarello MD (2012b) Quality, bioactive compounds and antioxidant activity of strawberries grown in the Brazilian savannah and stored at different temperatures. Journal of Food Agriculture Environment, 10:165-171.

Pinto MS, Lajolo FM \& Genovese MI (2007) Bioactive compounds and antioxidant capacity of strawberry jams. Plant Foods for Human Nutrition, 62:127-131.

Rein M (2005) Copigmentation reactions and color stability of berry anthocyanins. PhD Thesis. University of Helsinki, Helsinki. 87p.

Seeram NP, Lee R, Scheuller HS \& Heber D (2006) Identification of phenolic compounds in strawberries by liquid chromatographic analysis of phenolic compounds in strawberries by liquid chromatography electrospray ionization mass spectroscopy. Food Chemistry, 97:01-11.

Shin Y, Liu RH, Nockc JF, Holliday D \& Watkins CB (2007) Temperature and relative humidity effects on quality, total ascorbic acid, phenolics and flavonoid concentrations, and antioxidant activity of strawberry. Postharvest Biology Technology, 45:349-357.

Singleton VL, Orthofer R \& Lamuela-Raventos RM (1999) Analysis of total phenols and other oxidation substrates and antioxidants by means of Folin-Ciocalteu reagent. Methods in Enzymology, 299:152178.

Soares S, Kohl S, Thalmann S, Mateus N, Meyerhof W \& Freitas V (2013) Different phenolic compounds activate distinct human bitter taste receptors. Journal of Agricultural Food Chemistry, 61:1525-1533

Stone H \& Sidel JL (2004) Sensory Evaluation Practices. $3^{\text {rd }}$ edition. London, Elsevier Academic Press. 377p.

Tang C, Heymann H \& Hsieh F (2000) Alternatives to data averaging of consumer preference data. Food Quality and Preference, 11:99-104.

Tiwari BK, O'donnell CP, Patras A, Brunton NP \& Cullen PJ (2009a) Effect of Ozone Processing on Anthocyanins and Ascorbic Acid Degradation of Strawberry Juice. Food Chemistry, 113:1119-1126.

Tiwari BK, O'donnell CP, Patras A, Brunton NP \& Cullen PJ (2009b) Stability of Anthocyanins and Ascorbic Acid in Sonicated Strawberry Juice during Storage. European Food Research and Technology, 228:717-724.

Weber F, Greve K, Durner D, Fischer U \& Winterhalter P(2013) Sensory and Chemical Characterization of Phenolic Polymers from Red Wine Obtained by Gel Permeation Chromatography. American Journal of Enology and Viticulture, 64:15-25.

Wicklund T, Rosenfeld HJ, Martinsen BK, Sundfor W, Lea P, Bruun T, Blomhoff R \& Haffner K (2005) Antioxidant capacity and color of strawberry jam as influenced by cultivar and storage conditions. Food Science Technology, 38:387-391. 